\title{
CONTRIBUIÇÕES ÀS PESQUISAS SOBRE O USO SUSTENTÁVEL DE RECURSOS NATURAIS NO RIO GRANDE DO NORTE
}

\author{
H.C.D.PIMENTA ${ }^{1}$, F.L.S.NASCIMENTO \\ Instituto Federal de Educação, Ciência e Tecnologia do Rio Grande de Norte \\ handson.pimenta@ifrn.edu.br ${ }^{1}$
}

Submetido em 24/12/2019 - Aceito em 24/12/2019

DOI: $10.15628 /$ holos.2019.9329

No último editorial da Revista Holos do ano de 2019 apresentamos o Dossiê "Uso Sustentável de Recursos Naturais", enquanto resultado do trabalho de pesquisas realizadas no âmbito institucional, contributo à área de Ciências Ambientais e à sociedade do Rio Grande do Norte.

O Programa de Pós-Graduação em Uso Sustentável de Recursos Naturais (PPgUSRN), do Instituto Federal do Rio Grande do Norte (IFRN) Campus Natal Central, foi iniciado em 2015 e tem por objetivo principal formar profissionais, em nível de pós-graduação stricto sensu, interessados em atuar com estudos e técnicas interdisciplinares relacionados com o uso e o aproveitamento sustentável de recursos naturais, na qualidade de docentes, consultores e técnicos.

A sustentabilidade de todos os tipos de recursos naturais emerge como uma estratégia de alinhamento dos objetivos organizacionais demandados socioambientalmente. Assim, no PPgUSRN a produção de pesquisa aplicada é inovadora e interdisciplinar, focada no desenvolvimento de práticas relacionadas aos usos dos recursos naturais por duas linhas de pesquisa: sustentabilidade e gestão dos recursos naturais e saneamento ambiental.

A linha de sustentabilidade e gestão dos recursos naturais propõe a compreensão de ações, estratégias e procedimentos voltados à organização e à implementação de políticas públicas como também iniciativas para o desenvolvimento de instrumento de gestão dos recursos naturais nos âmbitos público, privado e do terceiro setor - e à geração de conhecimentos básicos e aplicáveis em estudos de indicadores e a práticas de sustentabilidade dos recursos naturais.

A linha de pesquisa em saneamento ambiental tem por finalidade precípua contribuir para a produção de conhecimentos, tecnologias e técnicas que promovam a preservação e a conservação do meio ambiente, enfatizando: o controle da poluição das águas, do ar e do solo; o reuso de águas, o uso produtivo e o controle de efluentes em estações de tratamento de água e de efluentes; a gestão integrada; o desenvolvimento de metodologias viáveis para o tratamento e o reaproveitamento de resíduos sólidos e biossólidos; e a avaliação de indicadores de contaminação ambiental.

Os trabalhos aqui apresentados foram produzidos por docentes e egressos do PPgUSRN. Os trabalhos estão alinhados com as linhas de pesquisa do programa, abordando temáticas como avaliação da qualidade de efluentes para reuso, avaliação da qualidade da água para fins de balneabilidade, gestão de resíduos urbanos, geoprocessamento, diagnóstico ambiental de comunidade rural e práticas de gestão ambiental em atividades produtivas, conforme detalhes a seguir:

\section{Qualidade de água e efluentes}

- $\quad$ Avaliação da qualidade da água do Rio Potengi a partir dos padrões estabelecidos nas resoluções do Conselho Nacional de Meio Ambiente $n^{\circ}$ 357/05 e 274/00 de forma a 
inteirar a comunidade sobre o nível de poluição nos trechos do rio que são utilizados para balneabilidade;

- $\quad$ Avaliação da qualidade da água produzida proveniente da indústria petrolífera no nordeste brasileiro no município de Mossoró-RN e seu potencial uso na irrigação; e

- $\quad$ Avaliação do tratamento de efluentes e a produção de água de reuso para fins agrícolas no campus do IFRN de São Paulo do Potengi, Brasil.

\section{Gestão de resíduos sólidos urbanos}

- Índice de Condição de Gestão de Resíduos Atualizado, visando à observância obrigatória pelo gestor público na gestão dos resíduos sólidos municipais.

\section{Geoprocessamento}

- $\quad$ Espacialização das manchas de óleo e graxa na zona portuária de Natal-RN através de técnicas de interpolação IDW e krigagem.

\section{Diagnóstico ambiental de comunidade rural}

- Diagnóstico ambiental de comunidades rurais de Currais Novos, localizadas na Microbacia do Rio Cobra, município de Jardim do Seridó, do Semiárido Potiguar sob a ótica da mitigação de efeitos da desertificação.

\section{Práticas de gestão ambiental em atividades produtivas}

- Indicadores ambientais para mensurar a gestão hídrica, energética e a gestão de resíduos sólidos para o ambiente organizacional com foco na área de ensino, no caso, o Instituto Federal de Educação, Ciência e Tecnologia do Rio Grande do Norte;

- $\quad$ Avaliação de aspectos e impactos ambientais de um laboratório de análises físicoquímico do IFRN pelo método "Failure Mode and Effects Analysis" e proposição de medidas para controle;

- Diagnóstico ambiental e de processos da lavra de rocha ornamental; e

- $\quad$ Produção mais limpa nos processos da lavra de rocha ornamental.

Compartilhamos a alegria de difundir o conhecimento gerado pelas pessoas que compõem o PPgUSRN aos leitores o Dossiê "Uso Sustentável de Recursos Naturais".

À leitura!

Natal, 24 de dezembro de 2019.

Professor Handson Claudio Dias Pimenta

Professora Francinaide de Lima Silva Nascimento

\section{CONTRIBUTION TOWARDS RESEARCH ON SUSTAINABLE USE OF NATURAL RESOURCES IN RIO GRANDE DO NORTE IN BRAZIL}

In our last 2019 editorial in the Holos Journal, as a result of institutional research a dossier regarding "Sustainable use of Natural Resources" was published. It is a contribution to the area of Environmental Sciences for the Rio Grande do Norte society in Brazil.

The Post Graduate Program in Sustainable Use of Natural Resources (PPgUSRN) of the Federal Institute of Rio Grande do Norte in Brazil in its Natal Central Campus began its activities in 2015. The main purpose of the program is to train and educate professionals such as professors, 
consultants and technicians or those who have interest in studying and working with interdisciplinary techniques related to sustainable use of natural in stricto sensu postgraduate level.

Sustainability issues regarding all types of natural resources emerge as a strategy that works towards organizational environmental agenda. Thus, at PPgUSRN, applied research production is considered of innovative and interdisciplinary nature. This type of research is focused in the development of practices related to the use of natural resources in two areas of research: sustainability and natural resource management as well as environmental sanitation.

The research area regarding sustainability and natural resource management aims to comprehend actions, strategies and procedures towards the organization and implementation of public policies as well as initiatives that relate to the development of a natural resource management for public, private and third sector levels. It also considers the generation of basic and applicable knowledge studies that aim the acknowledgement of indicators in natural resource sustainability practices.

The research area relates to environmental sanitation aims to contribute to knowledge production, technology and techniques that promote and preserve environmental conservation. The research also emphasizes water control, air and soil pollution; water reuse, productive use and effluent control in water and wastewater treatment in plants; integrated management; the development of viable methodologies for the treatment and reuse of solid and biosolid wastes; and the evaluation of studies that considers environmental contamination indicators.

The articles were written by professors and alumni of the referred post graduate program and are aligned to their research areas. The research focuses on issues such as water effluent quality, reuse, quality assessment for bathing purposes, urban waste management, geoprocessing, environmental diagnosis of rural community and environmental management practices in productive activities, as follows:

\section{Water and Effluent quality}

- Evaluation of water quality regarding the Potengi River considering standards present in the resolutions $n^{\circ} 357 / 05$ e 274/00 of the Brazilian National Environmental Council as a means to inform population on the pollution levels in the different parts of the river used for bathing purposes;

- Evaluation of water quality that is originated and produced in the oil industry in northeastern Brazil in the municipality of Mossoró in Rio Grande do Norte and its irrigation potential use; and

- Evaluation of the effluent treatment and reuse water production for agricultural purposes in the Federal Institute of Rio Grande do Norte Campus in the municipality of São Paulo do Potengi in the northeastern part of Brazil.

\section{Urban solid waste management}

- Updates in Waste Management Condition Index, aiming mandatory compliance by public managers in the administration of municipal solid waste.

\section{Geoprocessing}

- Spatialization of oil and grease stains in the Natal harbor area through IWD interpolation and kriging techniques. 


\section{Rural Community Environmental Diagnosis}

- Environmental diagnosis of rural communities of the municipality of Currais Novos, located in the Cobra River micro basin, Jardim do Seridó municipality, of the Semiarid area in the perspective of mitigating the desertification effects.

\section{Environmental management practices in productive activities}

- Environmental indicators used in order to measure water, energy and environmental solid waste management aiming Educational purposes, at the Federal Institute of Education, Science and Technology of Rio Grande do Norte;

- Evaluation of the environmental issues and impacts of the physicochemical analysis laboratory at the Federal Institute of Education, Science and Technology considering the method "Failure Mode and Effects Analysis" and the proposition of control measures;

- Environmental process and diagnosis related to ornamental rock mining; and

- Cleaner production in ornamental rock mining processes.

We share the joy of spreading knowledge generated by the people who are part of the Post Graduate Program in Sustainable Use of Natural Resources and present this to readers in the form of a dossier regarding "sustainable use of natural resources".

Happy reading!

December, 24th 2019

Professor Handson Claudio Dias Pimenta

Professora Francinaide de Lima Silva Nascimento

\section{CONTRIBUICIONES A LA INVESTIGACIÓN SOBRE EL USO SOSTENIBLE DE RECURSOS NATURALES EN RIO GRANDE DO NORTE}

En el último editorial de la Revista Holos del año 2019 presentamos el Dosier "Uso sostenible de Recursos Naturales" como resultado de investigaciones realizadas a nivel institucional, una contribución al área de Ciencias Ambientales y a la sociedad en Rio Grande do Norte.

El Programa de Postgrado en Uso Sostenible de Recursos Naturales (PPgUSRN), del Instituto Federal do Rio Grande do Norte (IFRN) Campus Natal Central, tuvo inicio en 2015 y tiene el objetivo general de preparar profesionales, en nivel de postgrado strictu sensu, interesados en actuar con estudios y técnicas interdisciplinares relacionadas al uso sostenible y explotación de los recursos naturales como docentes, consultores y técnicos.

La sostenibilidad de todos los tipos de recursos naturales surge como una estrategia para alinear los objetivos organizacionales exigidos social y ambientalmente. Así, la producción de investigación aplicada en el PPgUSRN es innovadora e interdisciplinar, enfocada en el desarrollo de prácticas relacionadas con el uso de los recursos naturales en dos líneas de investigación: sostenibilidad y gestión de los recursos naturales, y saneamiento ambiental. 
La línea sostenibilidad y gestión de los recursos naturales propone la comprensión de las acciones, estrategias y procedimientos para la organización e implementación de políticas públicas - así como iniciativas para el desarrollo de una herramienta de gestión de los recursos naturales a nivel público, privado y del tercer sector - y la generación de conocimiento básicos y aplicables en estudios de indicadores y prácticas de sostenibilidad de los recursos naturales.

La línea de investigación en saneamiento ambiental tiene el objetivo principal de contribuir a la producción de conocimiento, tecnologías y técnicas que promueven la preservación del medio ambiente, con énfasis en: control de la contaminación del agua, el aire y el suelo; reutilización de agua, uso productivo y control de efluentes en plantas de tratamiento de agua y aguas residuales; gestión integrada; desarrollo de metodologías viables para el tratamiento y reutilización de residuos sólidos y biosólidos; y la evaluación de indicadores de contaminación ambiental.

Los trabajos aquí presentados fueron producidos por docentes y graduados del PPgUSRN. Los trabajos están alineados con las líneas de investigación del programa, abordando temas como evaluación de la calidad de los efluentes de reutilización, la evaluación de la calidad del agua para el baño, la gestión de residuos urbanos, geoprocesamiento, diagnóstico ambiental de la comunidad rural, y prácticas de gestión ambiental en actividades productivas, como se detalla a continuación:

\section{Calidad del agua y efluentes}

- Evaluación de la calidad del agua del río Potengi según los estándares establecidos en las resoluciones del Consejo Nacional del Medio Ambiente $n^{\circ} 357 / 05$ y 274/00 para informar a la comunidad sobre el nivel de contaminación en los tramos del río que son utilizados para bañarse;

- Evaluación de la calidad del agua producida por la industria petrolera en el noreste de Brasil en el municipio de Mossoró-RN y su uso potencial en riego; y

- Evaluación del tratamiento de efluentes y la producción de agua de reutilización para fines agrícolas en el campus del IFRN de São Paulo do Potengi, Brasil.

\section{Gestión de residuos sólidos urbanos}

- Índice de Condición de la Gestión de Residuos Actualizado, buscando el cumplimiento obligatorio por parte del gerente público en la gestión de los residuos sólidos municipales.

\section{Geoprocesamiento}

- Especialización de manchas de petróleo y grasa en la zona portuaria de Natal-RN a través de técnicas de interpelación IDW y kringing.

\section{Diagnóstico ambiental de comunidad rural}

- Diagnóstico ambiental de comunidades rurales de Currais Novos, ubicadas en la microcuenca del río Cobra, municipio de Jardim do Seridó, del semi árido Potiguar con la perspectiva de mitigar los efectos de la desertificación. 
Prácticas de gestión ambiental en actividades productivas

- Indicadores ambientales para medir la gestión hídrica, energética y la gestión de residuos sólidos para el entorno organizacional centrado en el área de enseñanza, en este caso, el Instituto Federal de Educación, Ciencia y Tecnología del Río Grande del Norte;

- Evaluación de aspectos e impactos ambientales de un laboratorio de análisis físico-químicas del IFRN mediante el método "Failure Mode and Effects Analysis" y la propuesta de medidas de control;

- Diagnóstico ambiental y de procesos de minería de rocas ornamentales; y

- Producción más limpia en procesos de minería de rocas ornamentales.

Compartimos la alegría de difundir el conocimiento generado por las personas que componen el PPgUSRN a los lectores del dosier "uso sostenible de recursos naturales".

A la lectura entonces.

Professor Handson Claudio Dias Pimenta

Professora Francinaide de Lima Silva Nascimento 